\title{
Legal Framework of Kadhis' Courts in Zanzibar During the Post Colonial Era
}

\author{
Issa Babatunde Oba \\ Solicitor \& Advocate of the Supreme Court of Nigeria. Visiting lecturer Muslim University Morogoro, Tanzania. \\ PhD. Candidate School of Law. University of Dar es Salaam, Dar es salaam, Tanzania
}

\begin{abstract}
This paper is extracted from an unpublished doctoral thesis: An Investigation of Application of Islamic Jurisprudence on marriage in Kadhis Courts in Zanzibar and Kwara State of Nigeria. Kadhis courts had been in existence in Zanzibar long before the colonial era. The region is located along the east coast of Africa and it is part and parcel of United Republic of Tanzania. The court system of Arab legacy in this region of Africa. Kadhis courts assisted in maintenance of good governance and peaceful co-existence among different peoples within the region since independence. The court makes use of Islamic law in adjudication process on Muslim personal matters such as marriage, divorce, inheritance and other related matters. Kadhis courts are part of Islamic legal history of Zanzibar till contemporary era. The court system had witnessed different political regimes. Different reforms were made to make the court system relevant to the ever changing modern world. Kadhis courts do not exist in isolation but are within the hierarchal courts' structure of Zanzibar.
\end{abstract}

Keywords: Kadhis Courts; Islamic law; Muslim personal matters; Post-Colonial era and Zanzibar.

DOI: $10.7176 / \mathrm{JLPG} / 86-04$

Publication date:June $30^{\text {th }} 2019$

\section{Introduction}

A number of authors write on Kadhis courts system in relation to Muslim personal matters. Though these scholars appreciate the contributions of Kadhis courts in resolving Muslim personal matters, yet most scholars are quiet on the normative challenges of Kadhis courts during the post-colonial era.

Anderson discusses extensively on the trends of Kadhis courts in different regions of Africa. It is a comprehensive work on Islamic law which highlighted different issues pertaining to the operation of Islamic legal system in colonial Africa. ${ }^{1}$ The author emphases on East and West Africa during the colonial era, though a useful work that assist in better understanding of the subsequent development in Islamic legal system in Africa and beyond. This discourse focuses on Kadhis courts during the post-colonial era.

Makaramba discusses the secular nature of United Republic of Tanzania and the express provision of the constitution on the matter. ${ }^{2}$ This work is an asset to the present study since it highlights Muslim law in postcolonial Tanzania. In addition, it examines the politics of Muslim family and the compatibility of the pre-modern law and the nation state. This discourse also pin- points on the debate about reforms of Muslim family. This study evaluates trends in Kadhis courts in Zanzibar during the post-colonial period.

In the same vein, Majamba suggests on the possibility and rationale of establishing Kadhis courts in the Mainland. ${ }^{3}$ The author makes illustrations from selected jurisdictions to justify its position. The scholar remarks that the legal history reveals that the regulating subjects on the Mainland has evolved through a historical process and it is a product of specific society and norms. These scholarly works are useful reference materials for the present study because these works shed light on the recent political dimensions on the issue of Kadhis courts system has generated in contemporary times particularly in Tanzania

Majamba in another work provides some salient features of the Kadhis courts, and identifies some of the inherent weaknesses of the court system. ${ }^{4}$ The author overlooks to highlight on possible solutions. The present work addresses these gaps, suggests possible solutions and the way forward for Kadhis courts in Zanzibar.

Othman expatiates on judicial system in Zanzibar and explained on the existing courts system. ${ }^{5}$ The author writes little on Kadhis courts system. This is an area of lacuna on the subject matter which the current study examines. This study discusses Kadhis courts holistically with particular reference to Kadhis courts legal framework in Zanzibar.

Toufiq discusses Zanzibar courts system with slight differences from the previous scholar's work. ${ }^{6}$ Muskry

\footnotetext{
${ }^{1}$ Anderson, J.N.D., Islamic Law in Africa. London Frank Cass and Company Limited, 1970

${ }^{2}$ Makaramba, R.V. The Secular State and the State of Islamic Law in Tanzania. Shamil, J.,(ed) In Muslim Family Law in Sub Saharan Africa Colonial Legacies and Post Colonial Challenges Amsterdam, Amsterdam University Press, 2010.

${ }^{3}$ Majamba H.I., Possibility and Rationale of Establishing Kadhis courts in Tanzania Mainland. Paper presented at the $20^{\text {th }}$ REDET RMC Workshop, Dar es Salaam, $10^{\text {th }}$ November, 2007.

${ }^{4}$ Majamba, H.I., Perspectives on the Kadhis Courts in Zanzibar. Orient Journal of Law and Social Sciences Vol. 1, Issue No 2, January, 2007. ${ }^{5}$ Othman, M.O The Zanzibar Judicial System. In Chris Mama Peter and Immi Sikand (eds) The Judiciary in Zanzibar, Zanzibar. Zanzibar Legal Services Centre Publication Services, Book No 2, 2006 pp15-30

${ }^{6}$ Ibid., pp 40 - 58
} 
posits on the practical problems facing the judiciary in Zanzibar and silent on the normative challenges of Kadhis courts system. ${ }^{1}$ These authors explain the judiciary in Zanzibar in holistic matter. The present study, examines specifically Kadhis courts, within hierarchal courts structure of courts in Zanzibar.

Rweyemamu writes on the division of members of the parliament during the recent constitutional review in Tanzania. ${ }^{2}$ Members of the Parliament argue that the establishment of Kadhis courts contradicts article 19 of the constitution of United Republic of Tanzania. The contemporary update of this write up acts as compass on for the present work.

This paper examines the legal framework of Kadhis Courts during the post-colonial era. The frame of reference of the discourse includes the historical background of justice system of Tanzania, Islamic legal history of Zanzibar, and the Court of Appeal of Tanzania. The paper also evaluates the significance of High Court of Zanzibar on Muslim personal matters, discusses Magistrate courts; primary courts, district courts, and regional courts. The focal point of the paper is Kadhis court system in Zanzibar. The discourse evaluates the chief Kadhis court and Kadhis courts within the legal structure of Zanzibar. Also, language of the court system, jurisdiction of the court, and applicable law explained. In addition. The paper examines the procedural law aspects and recruitment, appointment and promotion of the staff of the courts. The exposition assesses the inherent weaknesses of Kadhis courts and the way forward.

\section{Historical Background of Justice System of Tanzania}

The United Republic of Tanzania is a nation with two judicial systems since the post-colonial era. ${ }^{3}$ The country is located along the east coast of Africa has a unique legal system. This country is bounded in the north by Uganda and Kenya in the south by Mozambique, Zambia and Malawi while in east by the Indian Ocean and in the west by Burundi, Rwanda and Congo. ${ }^{4}$ The population is estimated to be forty-eight million. ${ }^{5}$ There are approximately one hundred and thirty ethnic groups in Tanzania; the natives speak indigeneous laguages. The official languages of the nation are Kiswahili and English. In addition, many residents also speak Arabic. ${ }^{6}$ This region of Africa created different systems of adjudication process for the Europeans and native peoples. ${ }^{7}$ Essentially the natives of what is now known as the United Republic of Tanzania are the peoples of Tanganyika and the indigenous people of Zanzibar. ${ }^{8}$ The Germans had influence on the natives of mainland Tanganyika judicial system. ${ }^{9}$ This was because the legal arm of the administration had great connection with the executive branch of government and the Germans delegated adjudication of dispute process to the native heads, who also functioned as the executive wing of the administration. ${ }^{10}$ Under the Germans colonial legal regime, the natives' heads were supervised by the colonial district officials. ${ }^{11}$

The justice system was tell-guided by the German colonial masters who viewed indigenous system not sufficiently advanced if compared to that of the Europeans. ${ }^{12}$ The native legal system made use of local customs and norms and the application of common sense was vital in adjudication process. ${ }^{13}$

According to the Tanganyika legal history the Germans surrendered its colonies in East Africa to the British, who introduced the Tanganyika Order in Council as the legal instrument for the Territory in East Africa which included the natives of Tanganyika region. ${ }^{14}$ This was followed by the enactment of the Court Ordinance that monitored administration of system. The legal instrument separated the adjudication between the Europeans and the local people. ${ }^{15}$ But the court structure made provision for appeals from the native courts be sent to the colonial High Court. Under the legal system established by the British common law courts system was introduced which made provisions for the existence of a district magistrate court, a resident magistrate court and the High court. ${ }^{16}$ For the East African territories the British made use of the statutes it used in the British territories in India. ${ }^{17}$ However, when Tanganyika became an independent nation in 1961 it automatically became

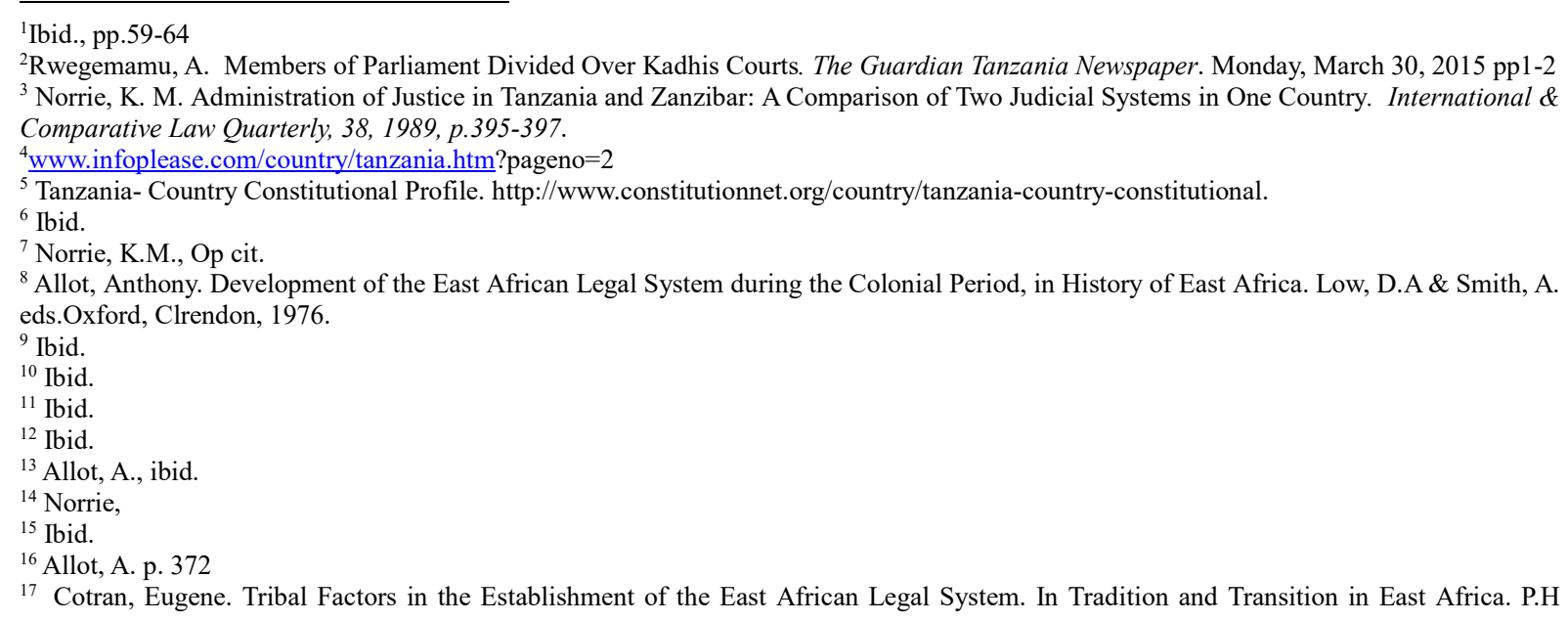


member of the British Commonwealth and the British repealed the system of appeal to the Privy Council. ${ }^{1}$ Since independence Tanganyika legal system had witnessed reforms, for instance the Magistrates' Court Acts came into existence in 1964, it was enacted in 1963, it came into force on $1^{\text {st }}$ July 1964 and a unitary court system of three-tier was introduced. ${ }^{2}$

This made provisions for the following court structure; primary courts, district court, Court of the Resident magistrate. ${ }^{3}$ Under this dispensation the lowest court was the primary court with jurisdiction in civil matters where the applicable law is customary or Islamic and settled disputes related to minor civil debts and matrimonial cases. ${ }^{4}$ The High court was next in the legal structure and it exercises jurisdiction strictly over Tanganyika exclusively. ${ }^{5}$

The apex court of United Republic of Tanzania is the Court of Appeal with jurisdiction to hear appeals from not only Tanganyika but also from Zanzibar. ${ }^{6}$

\section{Islamic Legal History of Zanzibar}

The Zanzibar archipelago is part and parcel of United Republic of Tanzania though with slightly different legal system. Zanzibar, an Indian Ocean archipelago located off the eastern coastline of Tanzania contains three large islands and a number of smaller ones. ${ }^{7}$ The island is separated from the mainland by a twenty-two miles channel. The region is unique because of the strong Arab-Muslim contact from the time immemorial with strong impact on the economics of the island. ${ }^{8}$ The British were the colonial masters of the region and with the protectorate system introduced the English legal system and tolerated the Sultan's system that was in existence before their arrival. ${ }^{9}$ Like in other East Africa territories, civil and criminal codes tailored that of British India. ${ }^{10}$ Under the legal regime introduced by the British a parallel courts' system existed for Zanzibar, the Sultan's courts for the natives and what was known as the subordinate courts. ${ }^{11}$ The legal structure made provision for the first, second and third class subordinate courts, kadhis' courts and juvenile courts. Kadhis courts under colonial legal regime had jurisdiction in Muslim personal matters. ${ }^{12}$

In 1963 the British granted Zanzibar self-government and this set the stage for a draft constitution for the nation. ${ }^{13}$ With the enactment of the Courts Decree in 1964 it brought an end to the Sultan's legal regime and the creation of the High Court, district courts, kadhis courts, primary courts and juvenile courts. When Zanzibar became an independent nation the British courts were abolished. ${ }^{14}$ In 1964 Zanzibar together with Pemba Island and some smaller Island joined with Tanganyika on the mainland to form the United Republic of Tanzania. ${ }^{15}$ Moreover, in 1969 with the enactment of the People's Court Decree a separate court structure came into existence in Zanzibar. ${ }^{16}$ This arrangement made provision for the People's Area Courts, the People District Courts, the Kadhis courts, the High Courts and the Supreme Council. ${ }^{17}$ There were also legislative reforms on legal regime of Zanzibar in 1984 and 1985 which assisted to improve the legal system of the region by the termination of the People's Courts system and the introduction of Common law in the judicial system. ${ }^{18}$ To this end, three types of courts system emerged in Zanzibar and include: the High Court of Zanzibar, the Kadhis Courts and the Magistrates Courts. ${ }^{19}$ The apex court in Zanzibar is the High Court of Zanzibar with unlimited jurisdiction over civil and criminal matters. ${ }^{20}$ The Court of Appeal of Tanzania has jurisdictions in Appeals from the High Court of Zanzibar. ${ }^{21}$ In the order of hierarchy, the Magistrate Courts are next to the High Court and

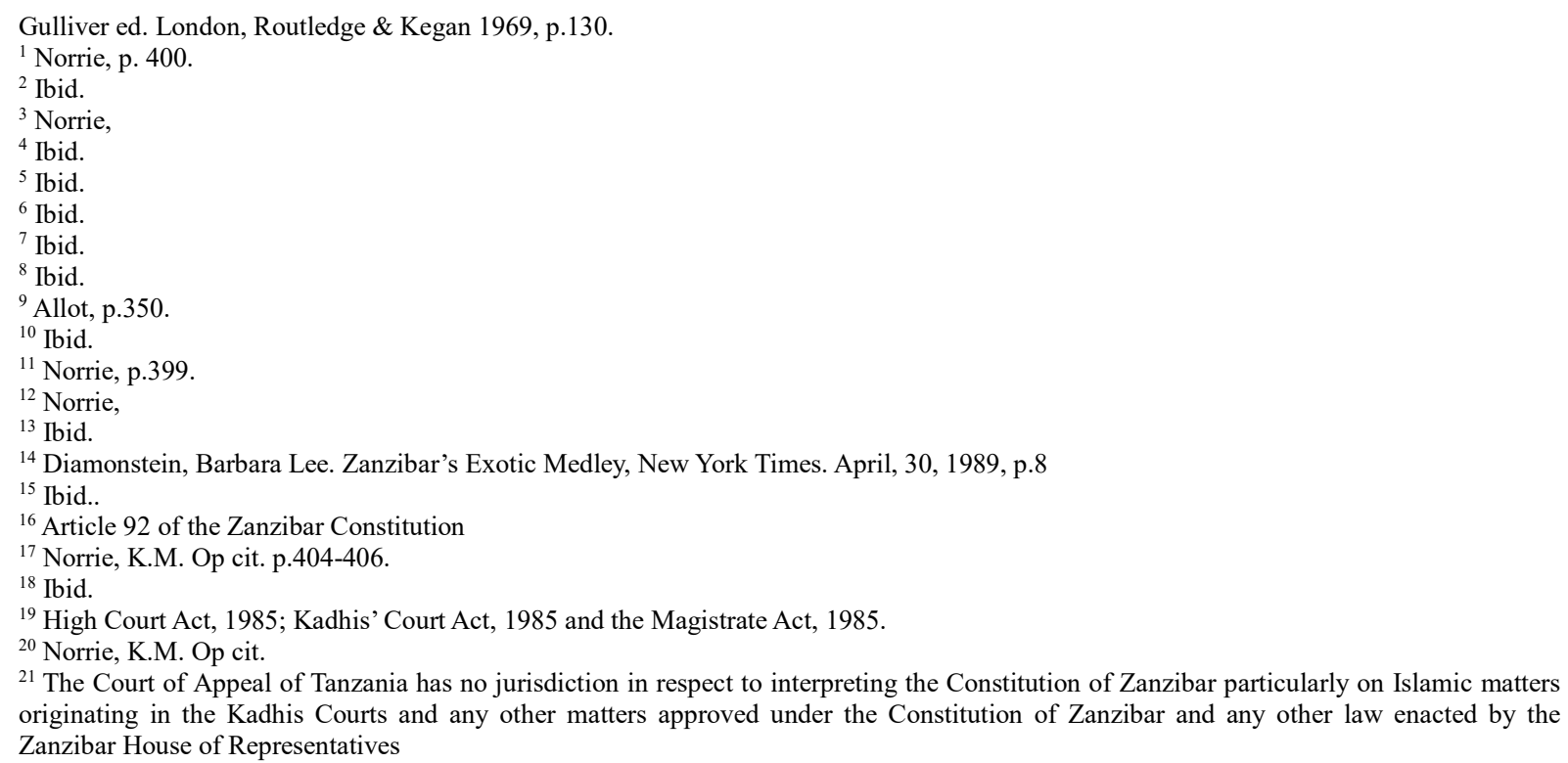


there are three types of Magistrate Courts. ${ }^{1}$ The classification include the primary magistrate court which has limited jurisdiction on civil and criminal powers. ${ }^{2}$ On the other hand, district court has original and appellate jurisdiction with slightly greater powers on civil and criminal matters if compared with the former. ${ }^{3}$ The resident magistrate courts have original and appellate jurisdiction and also with jurisdiction in cases from the lower magistrate courts. ${ }^{4}$

One of the greatest reforms in the legal history of Zanzibar was the constitutional recognition for the existence of the Kadhis Courts. ${ }^{5}$ This singular Act made provision for every district in Zanzibar to have Kadhis court and the constitutional provision of the position of the Chief Kadhis Court's court for Zanzibar. ${ }^{6}$ This reform made Kadhis courts to essentially have jurisdiction in Muslim personal matters particularly on issues marriage, divorce and inheritance provided where all the parties are Muslims. ${ }^{7}$ However, on the issue of credible evidence in Kadhi courts as recognized under Islamic jurisprudence was reformed. The 1985 Act amended the Islamic law position to this end, credibility of all evidence before the Kadhis courts in Zanzibar is not necessarily upon the number of witnesses who have given evidence. ${ }^{8}$ This is a landmark reform of Islamic jurisprudence for other nations with dual legal system to emulate in other make the Kadhis courts meet the needs of the Muslims in contemporary era.

The Chief Kadhis court has no original jurisdiction, but the Appeals from the Chief Kadhis court lie to the High Court of Zanzibar. ${ }^{9}$ In the High court the judge sits along with four sheikhs learned in Islamic jurisprudence. Cases at the High court are decided according to a majority vote and the decision of the court is final. ${ }^{10}$ In United Republic of Tanzania though there is the statutory provision for marriage in the Law of Marriage Act, but the family law is not considered a Union matter therefore the Law of Marriage Act is applicable only in the mainland Tanganyika and is not in use in Zanzibar. ${ }^{11}$

\section{4 .The Structure of Zanzibar Legal System.}

The apex Court of the United Republic of Tanzania legal structure is the Court of Appeal of Tanzania. Formerly, the Court of Appeal for East Africa and its services were enjoyed by members of East Africa Community. ${ }^{12}$ The jurisdiction of the court covered Kenya, Tanzania and Uganda. With the collapse of the East African Community in 1977, it had negative impact on one of its organ, the Court of Appeal for East of Africa. ${ }^{13}$ But the Act establishing Court of Appeal made provision that all High Court judges of the partner States are ex-officio members of the Court. Tanzania capitalized on this provision before it constituted its Court of Appeal on $15^{\text {th }}$ August, 1979. ${ }^{14}$ During the formative years the composition of the Court of Appeal of Tanzania was made up of the Chief justice and not less than two other justices of Appeal. ${ }^{15}$

\subsection{Court of Appeal of Tanzania}

Presently, with the number of Justices of Court of Appeal scholars argue with the growing population of the nation at least fifteen Justices are required to sit at apex court of justice. ${ }^{16}$ The Court of Appeal Tanzania handles all matters from the High Court of Zanzibar except matters on Muslim family cases because family law is not considered as a Union matter. ${ }^{17}$ The President of the United Republic of Tanzania appoints the Chief Justice of the Court of Appeal and other Court of Appeal Judges though also appointed by the President on the recommendations of the Chief Justice. ${ }^{18}$ The Court of Appeal of Tanzania is one the unifying factor between Tanzania Mainland and Zanzibar because the United Republic of Tanzania share this court system. ${ }^{19}$ The

\footnotetext{
${ }^{1}$ Magistrate Act, 1985

${ }^{2}$ Ibid.

${ }^{3}$ Ibid.

${ }^{4}$ Ibid.

${ }^{5}$ Kadhis Court Act, 1985

${ }^{6}$ Stiles, E.E., A Kadhi and His Court: Marriage, Divorce and Zanzibar's Islamic Legal Tradition. Unpublished Ph.D. Dissertation, Washingtion, Washington University, August, 2002, p. 288-90.

${ }^{7}$ Ibid.

${ }^{8}$ Ibid.

${ }^{9}$ Ibid.

${ }^{10}$ Ibid.

11 Oppermann, Brenda. The Impact of Legal Pluralism on Women's Status: An Examination of Marriage Laws in Egypt, South Africa, and the United States, 17 Hastings Women's Law Journal., p. 65-90.,2006

${ }^{12}$ Established by Article 80 of the Treaty of East African Cooperation 1967.

${ }^{13}$ Peter, C.M and Kijo-Bisimba, H. Law \& Justice in Tanzania: Quarter of A Century of the Court of Appeal, Dar es Salaam, Mkuki Na Nyota Publishers, 2007, pp.81-87.

${ }^{14}$ Ibid.

${ }^{15}$ Ibid.

${ }^{16}$ Ibid.

${ }^{17}$ Habermas, J. Multiculturalism and the Liberal State 47 Stan Law Review. 849, 850-51, 1995. Mitnick, E.J., Individual Vulnerability and Cultural Transformation, 101 Michigan Law Review. 1635, 1636-37, 1640, 2003.

${ }^{18}$ Article 118 (3) of te Constitution of United Republic of Tanzania.

${ }^{19}$ The Court of Appeal of Tanzania is item No. 21 on the list of Union Matters provided in Schedule One to the Constitution of the United
} 
Constitution of United Republic of Tanzania states that the judiciary is not a Union Matter ${ }^{1}$ within the Union. Tanzania Mainland and Zanzibar has its own judicial system.

\subsection{High Court of Zanzibar}

The Constitution of the United Republic of Tanzania recognizes the right of Zanzibar to have its own High Court. ${ }^{2}$ The Judiciary of Zanzibar main role is the interpretation of laws, adjudication of cases and administration and dispensation of justice in accordance to the country's laws. ${ }^{3}$ The emergence of the Zanzibar Court system can be traced to 1964, immediately after the 1964 revolution. ${ }^{4}$ The Zanzibar Government abolished the former Court System which was two-tier High Court structure, that is His and Her Majestic High Court which dealt with British subjects on the one hand, while the Sultan Court was for the subjects of the Sultan. ${ }^{5}$ With the revolution a single uniform court structure was established for all the subjects. The court's nomenclature now became the High Court of Zanzibar. ${ }^{6}$ The Industrial Court is a Division of the High Court of Justice. ${ }^{7}$ In addition, the 1964 revolution also abolished Subordinate Courts structure and the People Court of Zanzibar came into existence. ${ }^{8}$ In 1985 it was abolished and replaced with the present subordinate Courts and Magistrate Courts system came into being in Zanzibar. ${ }^{9}$

According to the Zanzibar constitution the top most court in the hierarchy is the High Court of Zanzibar. ${ }^{10}$ The Judiciary system of Zanzibar comprises of High Court and Subordinate Courts and it includes the Kadhi courts. This comprise of district Kadhis courts and are court of first instance and the Appellate kadhis court which is aappeal court. ${ }^{11}$ Other subordinate courts are the Magistrate courts and consists of the Primary Magistrate courts, District Magistrate courts and Regional courts. ${ }^{12}$ The Regional Magistrate courts handle matters that relate to children. ${ }^{13}$ The High Court of Zanzibar is a superior court of record to hear and determine any civil and criminal matters. The High Court hears appeals from the subordinate courts and has supervisory powers over all subordinate courts. ${ }^{14}$ During civil or criminal trials as well as in appeal cases the High Court may call not more than four assessors to give assistance to the judge as the may be. The opinions of the assessors are of no binding effects on the judge..$^{15}$ This provision does not apply to Muslim personal matters originating from the Kadhis' courts. ${ }^{16}$ The decision of the judge must be documented on courts' records. The language of the High Court of Zanzibar is Kiswahili or English. The Chief Judge may use his discretion on the language of the court. ${ }^{17}$ In Zanzibar Judges of the High Court are appointed by the President of the Revolutionary Government of Zanzibar in consultation with the Judicial Service Commission of Zanzibar. ${ }^{18}$

\section{Magistrate Courts}

The jurisdiction in Muslim Legal matters and the administration of justice under the present dispensation is based on 1985 legislation. To this end, the Magistrate courts are classified into three namely; the Primary Courts, District Courts, and Regional Courts. ${ }^{19}$

Republic of Tanzania. It is established vide Part Five of Chapter Five of the Constitution of the United Republic of Tanzania (as provided for Articles 116-123). It is also specifically enumerated in the Zanzibar Constitution of 1984 as provided for under Section 9899A, which are in Part Two of Chapter Six).

${ }^{1}$ See the judgment delivered by Hon. Mr. Msumi, J in a moot court organized at the University of Dar es Salaam, in a case which involved interpretation of article 20 of the Zanzibar Constitution on freedom of association; where it was clearly decided that article 28(2) of the Zanzibar Constitution had denied the Court of Appeal jurisdiction on cases related to the interpretation of the constitution and other matters. Also Shivji, G. Issa, The Legal Foundations of the Union in Tanzania's Union and Zanzibar Constitutions, Dar es Salaam, Dar es Salaam University Press, 1990, at p. 80 .

${ }^{2}$ Article 114 of the Constitution of United Republic of Tanzania, 1997 as amended.

${ }^{3}$ The Judiciary of Zanzibar. www.judiciaryzanzibar.go.tz

${ }^{4}$ Ibid.

${ }^{5}$ Ibid.

${ }^{6}$ Article 93(1) of the Constitution of Zanzibar, 1984 as amended.

${ }^{7}$ Section 80(1) of the Labor Relation Act, No 1, 2005.

${ }^{8}$ Issa, Shivji. Op.cit.

${ }^{9}$ Magistrate Court Act, 1985.

${ }^{10}$ Article 93(1) of the Constitution of Zanzibar, 1984 as amended.

${ }^{11}$ Kadhis Court Act, 1985.

${ }^{12}$ Magistrate Court Act, op cit.

${ }^{13}$ Children Act, No 6, 2011.

${ }^{14}$ Rutinwa, Bonaventura. Constitution and Legal System of East Africa: The Court System and Conflict of Law in Tanzania. Dar es Salaam, The Open University of Tanzania, 1996, p.93-94.

${ }^{15}$ Ibid.

${ }^{16} \mathrm{Ibid}$.

${ }^{17}$ Section 14 of the High Court Act.

${ }^{18}$ Section 94 (2) of the Zanzibar Constitution, 1984

${ }^{19}$ Magistrate Court Act, 1985. 


\subsection{Primary Courts}

A Primary Court is available in every district of Zanzibar. ${ }^{1}$ There is the constitutional provision for establishment of more than one court in each district of Zanzibar. ${ }^{2}$ The Judicial Service Commission appoints Magistrates for the Primary Courts. Magistrates presides over Primary Courts in Zanzibar. ${ }^{3}$ The Magistrate sits with not less than two assessors ${ }^{4}$ and arrive at its decisions in any issue, be it the question of adjourning the hearing, an application for bail, a question of guilt or innocence of any accused person, the determination of sentence, the assessment of any monetary award and all question and issues what so ever shall be decided by the vote of the majority. ${ }^{5}$ The jurisdiction of the Primary Courts are on civil, criminal matters and on matters relating to money and financial issues. On pecunary jurisdiction on civil matters, five million for immoveable property and one million for moveable property. ${ }^{6}$ On the service of the lawyers in the courts, advocates or State Attorney are prohibited from appearing before the Magistrates. ${ }^{7}$ But in Zanzibar litigants may be represented by Wakyts, ${ }^{8}$ in matters before the Primary Courts. ${ }^{9}$ The language of the court, in Primary Courts is Kswahili language. ${ }^{10}$

\section{2 District Courts}

The District Court is established under the Magistrate Act. ${ }^{11}$ This court exercises appellate and revisionary powers over the Primary Courts below it. ${ }^{12}$ District Court is established in every District of Zanzibar. ${ }^{13}$ This provision of the law is yet to be fulfilled in Pemba and Unguja Districts of Zanzibar up till recent times. ${ }^{14}$ The District Magistrate is appointed by the Judicial Service Commission. ${ }^{15}$ The qualification for the position of District Magistrate in Zanzibar is a diploma in Law or a degree in Law or equivalent. ${ }^{16}$ On the service of the lawyer under the district court in Zanzibar, advocates have right of audience before the district courts of Zanzibar. ${ }^{17}$ District Courts in Zanzibar have both original and appellate jurisdiction in criminal and civil cases. On pecuniary jurisdiction on civil matters, ten million is maximum for immoveable property and five million for moveable property. Appeals from the Primary Courts lie to the District Courts. ${ }^{18}$ The language of the District Court of Zanzibar is either Kiswahili or English as the Chief Judge may direct. ${ }^{19}$

\subsection{Regional Courts}

The Magistrate Act makes provision for the establishment of a regional court in each region of Zanzibar. ${ }^{20}$ Resident Magistrates preside over regional courts. A Regional Magistrate is appointed by the Chief Judge. This judicial position is for holders of degree in law and not less than three years' experience. ${ }^{21}$ Regional Courts have criminal, civil, and pecuniary jurisdictions. On pecuniary jurisdiction on civil matters the value of the subject matter does not exceed fifty million for immoveable property and thirty million for moveable property. In addition, it has original jurisdiction ${ }^{22}$ and appellate jurisdictions. ${ }^{23}$ And it performs supervisory functions over both district and primary courts. ${ }^{24}$

However, a Regional Magistrate is the chairperson of Juvenile Court and sits with two lay members of the public, the composition is usually gender friendly and such sittings are held in camera. ${ }^{25}$ The Chief Judge appoints resident magistrate for each region of Zanzibar. The Regional Court of Zanzibar is the same as the Resident Magistrates' Courts in Tanzania Mainland.

\footnotetext{
${ }^{1}$ Section 3(1), Magistrate Court Act, 1985.

${ }^{2}$ Section 3(3), Magistrate Court Act, 1985.

${ }^{3}$ Section 5(1), Magistrate Court Act, 1985.

${ }^{4}$ Section 6(1) Magistrate Court Act, 1985.

${ }^{5}$ Section 6(2), Magistrate Court Act, 1985.

${ }^{6}$ Section 4 Magistrate Court Act, 1985

${ }^{7}$ Section 8 (1) Magistrate Court, Act, 1985

${ }^{8}$ In Zanzibar Wakyts are not defined in the statute, but these are considered to be paralegal officials who hold certificate or diploma in Law.

${ }^{9}$ Section 8 (2) Magistrate Court, Act, 1985.

${ }^{10}$ Section 7 of the Magistrate Act, 1985.

${ }^{11}$ Section 9 (1) of the Magistrate Act, No 6 of 1985

${ }^{12}$ Section 17(1) of the Magistrate Act of 1985.

${ }^{13}$ Section 9 (1) of the Magistrate Act of 1985.

${ }^{14}$ Hussein, M.S and Masoud, K.M. Court System in Tanzania: A Bird Eye View. Pragyaan: Journal of Law. Volume 3, Issue 1. June 2013, p. 15 .

${ }^{15}$ Section 10(1) of the Magistrate Act of 1985

${ }^{16}$ Section 19(2) of the Magistrate Act of 1985.

${ }^{17}$ Section 32 of the Magistrate Act of 1985.

${ }^{18}$ Section 17 of the Magistrate Act of 1985.

${ }^{19}$ Section 15 of the Magistrate Act of 1985.

${ }^{20}$ Section 18(1) of the Magistrate Act of 1985.

${ }^{21}$ Section 19(3) of the Magistrate Act of 1985.

${ }^{22}$ Section 21(a) \& (b) of the Magistrate Act of 1985.

${ }^{23}$ Section 25 of the Magistrate Act of 1985.

${ }^{24}$ Section 19(1) of the Magistrate Act of 1985.

25 Section 22 of the Magistrate Act of 1985. See also Hussein, M.S and Masoud, K.M., Op cit.
} 


\section{Kadhis' Court System in Zanzibar}

One of the oldest court system in Zanzibar is the Kadhis court system. Literarily, Kadhi is an Arabic word which means a judge in a Muslim environment whose decisions are based on Islamic jurisprudence. ${ }^{1}$ From the classic era Kadhis traditionally had jurisdictionon Muslims legal matters applying Islamic law. Kadhis courts had long historical antecedent from the time of the advent of the Arabs along the east coast of Africa. ${ }^{2}$

\subsection{Kadhis' Courts}

Kadhis courts in Zanzibar are established by the Constitution of Zanzibar, the High Court Act. ${ }^{3}$ The courts are parallel to the Magistrates' courts under the current judicial structure of Zanzibar. ${ }^{4}$ According to the constitutional provisions, there are two Kadhis' Courts in Zanzibar. These are the Kadhis courts and the Chief Kadhi court of Zanzibar. ${ }^{5}$ In addition, in accordance to constitution guideline the House of Representatives of Zanzibar is empowered to enact law for the establishment of other courts than the High Court of Zanzibar and the Court of Appeal. ${ }^{6}$ Accordingly, pursuant to constitutional provisions the House of Representatives enacted the High Court Act and the Kadhis' Court Act in 1985. ${ }^{7}$ Hence, the establishment of Kadhis Courts in each of ten Districts of Zanzibar, and each has jurisdiction within the District in which it is established. ${ }^{8}$

The Act makes provision for the qualifications for the position of Kadhis in Zanzibar. First such candidate needs to profess and practice Islam with good understanding of Islamic jurisprudence. ${ }^{9}$ Though Kadhis Court are made up of Kadhis and are appointed by the Judicial Service Commission in consultation with the Chief Kadhis. ${ }^{10}$ In Zanzibar Kadhis are judicial officers for their appointment and promotion are based on the recommendation of Judicial Service Commission in accordance to civil service rules and regulations and belongs to the judicial arm of the government. ${ }^{11}$ In Zanzibar Kadhis Courts are endowed with independent budget allocation according to the provision of the statute. ${ }^{12}$

\subsection{Chief Kadhis' Court}

In Zanzibar, the Chief Kadhis Courts are established by the Constitution of Zanzibar. ${ }^{13}$ At the apex of Kadhis Court structure is the Chief Kadhi. Qualifications required is the same with that of other Kadhis except requisite experience is required of the office of Chief Kadhi. The Chief Kadhi is appointed by the president of Zanzibar. ${ }^{14}$ In Zanzibar, two offices of Chief Kadhis Courts are in existence, one established in Unguja the second one is located at Pemba. ${ }^{15}$ On the composition of the court, the Chief Kadhis Court is made of one senior Kadhi who assists the Chief Kadhi in adjudication process. ${ }^{16}$

\subsection{Language of the Kadhis' Courts}

Kadhis Courts' proceedings are not open to the public. The language of the court is Kiswahili. ${ }^{17}$ Parties involved in matters before the Kadhis Courts make their address in Kiswahili. ${ }^{18}$

In some cases judgments of the courts are written in Arabic scripts. Kadhis Courts are not courts of record. ${ }^{19}$ In Chapter 6, research findings show that the court files Annual Returns to the High Court

\subsection{Kadhis Courts' Jurisdiction}

Essentially the jurisdictions of Kadhis Courts are on Muslims' personal matters namely; marriage, divorce inheritance and other related matters. ${ }^{20}$ But the constitution is clear that all the parties involved in proceedings must profess Islam and the court may exercise territorial or subject matter jurisdiction within its area of

\footnotetext{
${ }^{1}$ Majamba, H.I. Possibility and Rationale of Establishing Kadhis Courts in Tanzania Mainland. Paper presented at the $20^{\text {th }}$ REDET RMC Workshop. Held in Council Chamber, University of Dar es Salaam on $10^{\text {th }}$ November, 2007.

${ }^{2}$ Ibid.

${ }^{3}$ Kadhis Court Act No 2 of 1985

${ }^{4}$ Kadhis Court Act No 3 of 1985 .

${ }^{5}$ Ibid.

${ }^{6}$ Article 100 of the Constitution of Zanzibar, 1984.

${ }^{7}$ Section 5(c) of the High Court Act must be read together with Section 3(2) of the Kadhis Act for clarity.

${ }^{8}$ Section 3(2) of the High Court Act 1985.

${ }^{9}$ Section 5(3) of Kadhis Court Act of 1985.

${ }^{10}$ Section 5(1) of Kadhis Court Act of 1985.

${ }^{11}$ Omari, Issa. Legal System in Tanzania Law and Courts. Mbeya, Penuel Printing, 2018.

${ }^{12}$ Section 28(1) of Kadhis Act of 1985.

${ }^{13}$ Section 3(2) of the Kadhis Court Act of 1985.

${ }^{14}$ Section 6 of the Kadhis Court Act of 1985.

${ }^{15}$ Section 4 (4) of the Kadhis Court Act of 1985.

16 Ibid.

${ }^{17}$ Majamba, H.I Perspective on Kadhis' Courts in Zanzibar, p.7.

${ }^{18}$ Ibid.

19 Ibid.

${ }^{20}$ Section 6 (1) of the Kadhis Court Act 1985.
} 
jurisdiction. ${ }^{1}$ From the composition and qualifications of Kadhis Courts officials, these courts are religious courts.

\subsection{Jurisdiction of the Kadhis' Courts}

The jurisdiction of Kadhis Courts are limited to Muslims personal matters in Zanzibar. ${ }^{2}$ The court system have jurisdiction on matters of strictly Islamic civil nature provided all the parties involved are Muslims. Indeed, consent of the parties are vital in jurisdictional scope to this court type. ${ }^{3}$ Accordingly, being a Muslim does not give the court an automatic jurisdiction or is not ipso facto gives an individual to the jurisdiction of the court system. ${ }^{4}$ In Zanzibar, there are Constitutional safeguards which guarantee the protection the citizens' right to freedom of religion and right not to be discriminated against in whatever form and right to access the courts. ${ }^{5}$ Kadhis Courts in Zanzibar do adhere to doctrine of precedent. ${ }^{6}$ These courts are bounded only by doctrines of Islamic jurisprudence. These courts make use of the Quran and the tradition of the Prophet Mohammad. In Zanzibar Kadhis Courts abide by the doctrine of Shafii jurisprudence. ${ }^{7}$

\subsection{Jurisdiction of the Chief Kadhis Courts}

The Chief Kadhis Courts supervise the lower Kadhis Courts and these courts have appellate jurisdiction on other Kadhis Courts in Zanzibar. These courts hear and determine appeals for the matters that originated from the Kadhis Courts. ${ }^{8}$ The Chief Kadhis Courts in Zanzibar do not have original jurisdiction, but only act as an appellate court for decisions from Kadhis Courts. ${ }^{9}$ In order for the Chief Kadhis Court to perform its appellate jurisdiction the composition is made of the Chief Kadhi and one senior Kadhi in one appeal. On the other hand, the Chief Justice of Zanzibar has discretional power on composition of the court. ${ }^{10}$ Appeals on the decisions of Chief Kadhis Courts lie to the High Court of Zanzibar. ${ }^{11}$ In cases of difference of opinions on Muslim personal matters there is the statutory provision for the office of Mufti who advised on jurisprudential matters of Islamic law. ${ }^{12}$

For the High Court to exercise their appellate jurisdiction for appeals from the Chief Kadhis Court. The High Court is presided by a single judge in the presence of four Sheikhs who are learned in Islamic law. ${ }^{13}$ These experts are essential for proper composition on matters of appeal on Muslims' matters and are regarded as members. ${ }^{14}$ However, the High Court may require external experts to assist to interpret ambiguous matters in Islamic jurisprudence. ${ }^{15}$ As in the Zanzibar case of Masoud Ali Kombo and others versus Khalid Ali Kombo and others. In the said case the Attorney General of Zanzibar functioned as amicus curiae for the purpose of application of Islamic law. ${ }^{16}$

On issues of Muslims' personal matters the High Court's decision on such appeal is based on the majority opinion of the members. ${ }^{17}$ The decision of the High Court of Zanzibar is final on matters of Islamic Law and cannot be subject of appeal to the Court of Appeal of Tanzania. ${ }^{18}$ Scholars argue that the High Court of Zanzibar as the final court of appeal on civil matters ousts the Court of Appeal appellee's jurisdiction and that justice is side tracked. On the other hand, other scholars contend that since the Court of Appeal has no original jurisdiction it does not administer justice. ${ }^{19}$

\subsection{Applicable Laws by the Kadhis Courts.}

Although Kadhis Courts adhere to Islamic law in the determination of matters before the court, yet the constitution provides for applicable law in the Kadhis Courts. ${ }^{20}$ All Kadhis Courts including the Chief Kadhis

\footnotetext{
${ }^{1}$ Section 3(3) of the Kadhis Court Act 1985.

${ }^{2}$ Section 3(3) of the Kadhis Court Act of 1985.

${ }^{3}$ Ibid.

${ }^{4}$ Ibid.

${ }^{5}$ Article 12 and 19 of the 1984 Constitution of Zanzibar, 2002.

${ }^{6}$ Majamba, H.I Op cit, p.6.

${ }^{7}$ Majamba, H.i, Ibid.

${ }^{8}$ Section 4(4) of the Kadhis Court Act of 1985.

${ }^{9}$ Section 10(1) of the Kadhis Court Act of 1985.

${ }^{10}$ Section 4(4) of the Kadhis Court Act of 1985.

${ }^{11}$ Section 10(2) of the Kadhis Court Act of 1985.

${ }^{12}$ Mufti Act No. 9 of 2001.

${ }^{13}$ Section 10(3) of the Kadhis Court Act of 1985.

14 Ibid.

15 Omari, Issa. Legal System of Tanzania Laws and Courts, Mbeya, Penuel Printing, 2014, p.213.

${ }^{16}$ Civil Appeal No 16 of 1987, High Court of Zanzibar, (Unreported)

${ }^{17}$ Rutinwa Bonaventura., Constitution and Legal System of East Africa: The Court System and Conflict of Laws in Tanzania. Dar es Salaam.

The Open University of Tanzania, Faculty of Law, 1996

${ }^{18}$ Section 10(3) of the Kadhis Court Act of 1985.

${ }^{19}$ Fimbo, G.M., Constitutionalism and Court Structure of Tanzania, Dar es Salaam, DUP, 1992.

${ }^{20}$ Section 7 of the Kadhis Court Act of 1985.
} 
Courts are not discriminate on grounds of religion, sex or otherwise. ${ }^{1}$ In addition, Kadhis Courts are to decide matters upon an assessment of credibility of all evidence before the court and not upon the number of witnesses who have given evidence.

\subsection{Procedural Aspects of Kadhis Courts}

The Constitution of Zanzibar makes reforms on the procedural aspects of Kadhis Courts which differ from that of Islamic law practice. The law applicable in the Kadhis Courts is not codified. But there is an express provision in the general law would negate Islamic law to the extent of such inconsistency. ${ }^{2}$ Moreover, Kadhis have discretional power to interpret Islamic law and pronounce judgments on matters brought before the courts. ${ }^{3}$ According to scholars for over two decades now the Kadhis Courts have being existence without rules of procedure and practice as required by the law that established the court system. ${ }^{4}$ Despite the fact that the Chief Justice of Zanzibar is empowered to make rules and provides for the procedure and practice to be applied in the Kadhis Courts. ${ }^{5}$ The Chief Justice of Zanzibar is yet to exercise this discretional power thereby creates lacuna of issue of practice procedure. To bridge this gap the Kadhis Courts make use of Civil Procedure Decree. ${ }^{6}$ This development demostrates the impact of Common law influence on adjudication process on Muslims' matters in Zanzibar. $^{7}$

However, proceedings before any Kadhis Court cannot be challenged the ground that the law and rules of evidence applicable in the High Court are applied except that such an application resulted in miscarriage of justice. ${ }^{8}$

\subsection{Recruitment, Appointment and Promotion}

The recruitment, appointment and promotion of Kadhis are guided by civil service rules and regulations. Therefore, Kadhis Courts officials are civil servants and are on the pay roll of the executive arm of Government of Zanzibar. ${ }^{9}$ The Chief Kadhis is appointed by the President and has to be well versed in Islamic law. ${ }^{10}$ Such appointments are made on the recommendations of the Judicial Service Commission. ${ }^{11}$ On the qualifications for the position of Kadhi, only a Muslim can be appointed. ${ }^{12}$ Since the requirements include mainly; that the person follow Muslim religion and must possess knowledge of Islamic jurisprudence applicable to any sect or sects of Muslims. Non- Muslims are not taken into consideration for the position of Kadhi in Zanzibar. ${ }^{13}$ From available statistics several Kadhis that have been appointed are of Diploma in Islamic law background, by extension the minimum qualification for the position of Kadhi is Diploma in Islamic law. ${ }^{14}$

\section{Inherent weaknesses of Kadhis Courts.}

Contemporary Islamic scholars assess Kadhis Courts in Zanzibar during the post-colonial era from the perspective of competency of the courts in line with the best practices under international law and international human rights norms. In the first instance, the non-appointment of women on the Kadhis bench. This has been the trend since independence of Zanzibar. This position is contrary to contemporary law and norms. The trend show cases gender inequality and women status have drastically changed from that of the classical period of Islam. Jurists however argue that matters concerning Islamic legal system be examined from historical context for better understanding of the issue at stake.

This school of thought, posits that there is no justification for women to be made Kadhis since there is no reference from the Quran or the Sunnah of the Prophet. The group argue further that Islam does not accommodate women to be appointed into certain leadership position such as Kadhis, Imam, to lead Muslim prayers or walii in marriage. Scholars explain that advertisement for positions of Kadhis are gender friendly, open to male and female members of the society. But that women ordinarily do not apply for the positions. Possibly women in Zanzibar have accepted their ordained status by God. Another inherent weakness of the Kadhis Courts in Zanzibar. This has to do with political consideration rather than merits. Such political consideration affects the competency of such appointees. This affects job performance of the Kadhis so

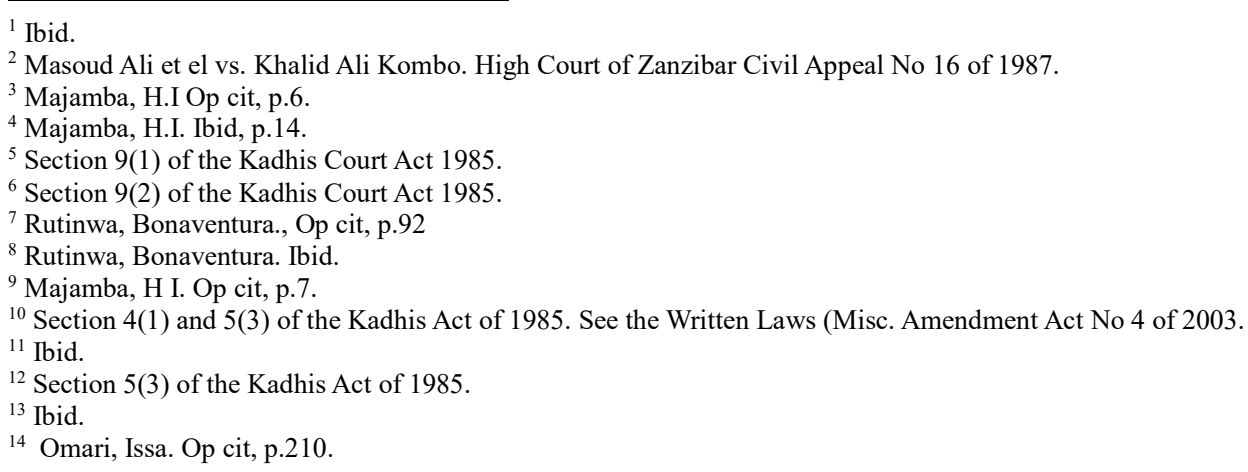


appointed in that manner since due process of appointment are often ignored.

In the same vein, the non-appointment of Muslims is another area of criticism of the Kadhis Courts system. This position since post-colonial era is not in line with best practices under international law and international human rights norms. Modern jurists however contend that adjudication process on Muslim personal matters is faith based. This therefore explains why non-Muslims are not given consideration for the appointment as Kadhis. Contemporary world is a global village and is ever changing. Most Kadhis are not computer literate and their offices lacked internet services. Computer literacy is not only necessary but it would enhance judicial performance. International connectivity would assist to understand modern trend in adjudication process as it is related to Muslim personal matters in other regions of the world. Despite the shortcomings of the courts' system. It provides an alternative means of adjudication that is friendly to the cultural norms with the people of Zanzibar. With appropriate reforms of the Kadhis Courts, the courts shall to be relevant to adjudication process on Muslim personal matters in Zanzibar for a very long time to come.

\section{Way forward for Kadhis Courts.}

This paper suggests that there is the need for a comprehensive review of the legal framework and institutional arrangements to meet the changing trends in modern era. Professional legal training should be given to those that hold the position of Kadhis. This may enhance job mobility within the judiciary. Kadhis courts are faith based adjudication mechanisms. Religion should therefore be used in the promotion of peaceful co-existence of the peoples of Zanzibar and Kwara State of Nigeria. Refreshal training programs be packaged for Kadhis from time to time and they should be exposed international conferences and workshops on matters related to Islamic jurisprudence. In addition, the study recommends more research works in Shafii jurisprudence the official maddhab of the region.

This effort will expand the frontiers of knowledge of Islamic law for the well-being of the people of Zanzibar. To be able to achieve this laudable goal, all published works in relation to Shafii jurisprudence written in Arabic be translated into other languages for these works to be useful and accessible to jurists and scholars without knowledge of Arabic. By and large, this paper suggests that Kadhis are given comprehensive computer training to assist them in their daily assignments. In fact, their offices as a matter of urgency need to be connected to the internet in order for them to have contemporary touch of development on marital jurisprudence in other Muslim regions of the world. Also, the discourse recommends that women be appointed as Kadhis due their advancement in education in recent times.

\section{Conclusion}

Islamic law legal regime had long historical antecedent in Zanzibar. The legal framework and institutional arrangements of the courts had undergone reforms since independence. The courts are creation of the statute and are integral part of hierarchical legal structure. Furthermore, the courts are under the supervision of the High Court of Zanzibar. More importantly, in contemporary times, Kadhis Courts file annual returns to High Court of Zanzibar in line with best practices under international law and international human rights norms. Also, High Court of Zanzibar hear appeal cases from the Chief Kadhis' Court and thereby functions as the final appeal for cases on Muslim personal matters. Similarly, the Judicial Service Commission supervises appointment, promotion and discipline of Kadhis. In Zanzibar, there is statutory recognition of the office of mufti to enhance adjudication process on Muslim personal matters. Kadhis Courts will continue to be relevant to adjudication process on Muslim personal matters since it is part Arab legacy in the region.

\section{ACKNOWLEDGMENT}

The research gave me the opportunity to assess fellow Muslims in Zanzibar on the impact of maddhab on the lives of Muslims. My special gratitude is spread to many people who have contributed one way or the other, who encouraged in inspiring, guiding and giving me support, without whom I may not have completed this laudable task. I am most grateful to God for his favours and support over the period of my study. I give special thanks to God for my family and my daughter, Aisha who was with me for a better of the programme. My family has tolerated and sacrified the huge demands of this Ph.D. on my sanity and time. I acknowledge them for their support and patience.

My first supervisor, Prof M.S. Hussein has been an inspiration and strong pillar of support both personally and professionally. I am most grateful. I thank the Almighty God for my supervisor, Prof. G.M Fimbo who guided me thoroughly to the success of the Ph.D study. He has set good examples for me and guided me with determination. I am eternally grateful to Prof. G.M Fimbo your professional advice and words of encouragement. I must also thank Professors. Nditi, M.I. Majamba, Kamaga and other erudite great scholars of the School of Law, University of Da es Salaam for their academic advice and encouragements throughout my period of study. 


\section{References}

1. Anderson, J.N.D., Islamic Law in Africa. London Frank Cass and Company Limited, 1970.

2. Civil Appeal No 16 of 1987, High Court of Zanzibar, (Unreported)

3. Diamonstein, Barbara Lee. Zanzibar's Exotic Medley, New York Times. April, 30, 1989.

4. Diamonstein, Barbara Lee. Zanzibar's Exotic Medley, New York Times. April, 30, 1989, p.8

5. Fimbo, G.M., Constitutionalism and Court Structure of Tanzania, Dar es Salaam, DUP, 1992.

6. High Court Act, 1985; Kadhis' Court Act.

7. The Magistrate Act, 1985.

8. Majamba H.I., Possibility and Rationale of Establishing Kadhis courts in Tanzania Mainland. Paper presented at the $20^{\text {th }}$ REDET RMC Workshop, Dar es Salaam, $10^{\text {th }}$ November, 2007.

9. Majamba, H.I. Possibility and Rationale of Establishing Kadhis Courts in Tanzania Mainland. Paper presented at the $20^{\text {th }}$ REDET RMC Workshop. Held in Council Chamber, University of Dar es Salaam on $10^{\text {th }}$ November, 2007.

10. Majamba, H.I., Perspectives on the Kadhis Courts in Zanzibar. Orient Journal of Law and Social Sciences Vol. 1, Issue No 2, January, 2007.

11. Makaramba, R.V. The Secular State and the State of Islamic Law in Tanzania. Shamil, J.,(ed) In Muslim Family Law in Sub Saharan Africa Colonial Legacies and Post- Colonial Challenges Amsterdam, Amsterdam University Press,2010.

12. Masoud Ali et el vs. Khalid Ali Kombo. High Court of Zanzibar Civil Appeal No 16 of 1987.

13. Omari, Issa. Legal System of Tanzania Laws and Courts, Mbeya, Penuel Printing, 2014, p.213.

14. Othman, M.O The Zanzibar Judicial System. In Chris Mama Peter and Immi Sikand (eds) The Judiciary in Zanzibar, Zanzibar. Zanzibar Legal Services Centre Publication Services, Book No 2, 2006.

15. Rutinwa Bonaventura., Constitution and Legal System of East Africa: The Court System and Conflict of Laws in Tanzania. Dar es Salaam. The Open University of Tanzania, Faculty of Law, 1996. 